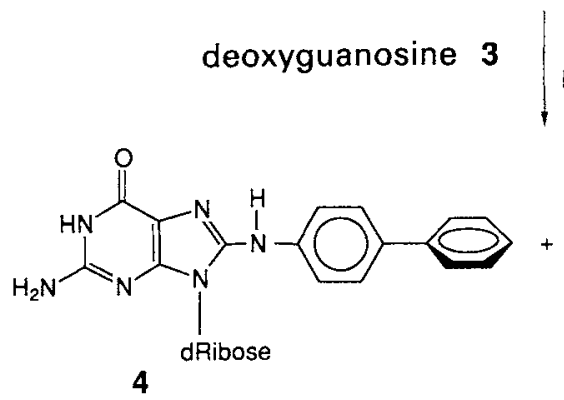

$37^{\circ} \mathrm{C}, \mathrm{N} \mathrm{Et}_{3}$ $\mathrm{EIOH}, \mathrm{CHCl}_{3}, \mathrm{H}_{2} \mathrm{O}$

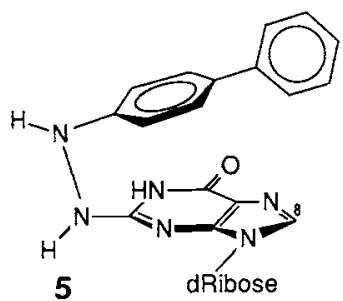

7.0) and ethanol at $50^{\circ} \mathrm{C} \cdot{ }^{[8]}$ The assumption that 2 is the reactive species in this reaction is confirmed by our findings. ${ }^{[9]}$

\title{
Experimental
}

2: A suspension of $4.00 \mathrm{~g}(21.6 \mathrm{mmol})$ of 1 in diethyl ether $(50 \mathrm{~mL})$ and triethylamine $(2.9 \mathrm{~mL}, 21.6 \mathrm{mmol})$ cooled to $-40^{\circ} \mathrm{C}$ was treated with a solution of acetyl cyanide [10] $(1.50 \mathrm{~g}, 21.6 \mathrm{mmol})$ in diethyl ether $(30 \mathrm{~mL})$ and the mixture vigorously stirred for $2 \mathrm{~h}$ between $-40^{\circ}$ and $-10^{\circ} \mathrm{C}$. After extraction with ice-water the aqueous phase was extracted at $0^{\circ} \mathrm{C}$ with $50 \mathrm{~mL}$ of $\mathrm{CH}_{2} \mathrm{Cl}_{2}$, the organic phases combined, dried with $\mathrm{MgSO}_{4}$, and the solvent removed in a rotary evaporator at $0^{\circ} \mathrm{C}$. The residue was rapidly dissolved at room temperature in $100 \mathrm{~mL}$ of ether/petroleum ether $(1 / 1)$ and $20 \mathrm{~mL}$ of $\mathrm{CH}_{2} \mathrm{Cl}_{2}$ and recrystallized at $-30^{\circ} \mathrm{C}$. The bright yellow crystals of 2 were dried at $-20^{\circ} \mathrm{C}$. Yield $3.98 \mathrm{~g}(81 \%)$; correct elemental analysis $(\mathrm{C}, \mathrm{H}, \mathrm{N}){ }^{1} \mathrm{H}$ NMR $\left(400 \mathrm{MHz}, \mathrm{CDCl}_{3}, 230 \mathrm{~K}\right): \delta=2.27(\mathrm{~s}, 3 \mathrm{H}), 7.15(\mathrm{~d}, 2 \mathrm{H}), 7.38(\mathrm{t}, 1 \mathrm{H})$, $7.47(\mathrm{t}, 2 \mathrm{H}), 7.58(2 \mathrm{~d}, 4 \mathrm{H}), 8.90(\mathrm{~N}-\mathrm{H}, 1 \mathrm{H}),{ }^{13} \mathrm{C} \mathrm{NMR}\left(400 \mathrm{MHz}, \mathrm{CDCl}_{3}\right.$, $230 \mathrm{~K}): \delta=19.3,116.9,126.7,127.0,127.7,128.7,136.7,140.1,145.4,170.8$. IR (Nujol): $\tilde{y}=3245,1755,1223 \mathrm{~cm}^{-1}$.

Reaction of 2 with $\mathbf{3}: 2$ (909 $\mathrm{mg}, 4.00 \mathrm{mmol}$ ) was treated with a solution of 3 $(1.07 \mathrm{~g}, 4.00 \mathrm{mmol})$ and triethylamine $(455 \mathrm{mg}, 4.50 \mathrm{mmol})$ in $70 \mathrm{~mL}$ of ethanol $/ \mathrm{CHCl}_{3} /$ water $(7 / 3 / 4)$ at $37^{\circ} \mathrm{C}$. After $1 \mathrm{~h}$ the solvent was removed; the adducts 4 and 5 were first separated over a silica gel column with $\mathrm{CHCl}_{3}$ / ethanol $(7 / 3)$ and then by preparative HPLC [11]. Yield (after silica gel chromatography): 4: $112 \mathrm{mg}$ (6\%); ${ }^{1} \mathrm{H}$ NMR ([D 6 DMSO, $400 \mathrm{MHz}$ : the data agree with those quoted in Ref. $[7 \mathrm{a}] .{ }^{13} \mathrm{C}$ NMR: $\delta=38.4,61.2,71.2,82.8,87.2$, $112.1,117.6,125.9,126.5,126.6,128.7,132.2,140.0,140.3,143.1,149.5,153.0$, 155.9. MS (FD): $m / z \quad 434\left(100 \%, M^{\oplus}\right), 318\left(61 \%, M^{\oplus}\right.$-dRibose + H). IR $(\mathrm{KBr}): \vec{v}=3329,2927,1680,1562,1356,1024,960,764,698 \mathrm{~cm}^{-1} ; 5: 55 \mathrm{mg}$ $(3 \%) ;{ }^{1} \mathrm{H}$ NMR $\left(\left[\mathrm{D}_{6}\right] \mathrm{DMSO}, 400 \mathrm{MHz}\right): \delta=2.12(\mathrm{~m}, 1 \mathrm{H}), 2.42(\mathrm{~m}, 1 \mathrm{H}), 3.47$ $(\mathrm{m}, 2 \mathrm{H}), 3.76(\mathrm{~m}, 1 \mathrm{H}), 4.28(\mathrm{~m}, 1 \mathrm{H}), 4.91(\mathrm{~s}, \mathrm{OH}), 5.21(\mathrm{~s}, \mathrm{OH}), 5.95(\mathrm{dd}, 1 \mathrm{H})$, 6.35 (s, $2 \mathrm{H},-\mathrm{NH}-\mathrm{NH}-), 7.37$ (d, $2 \mathrm{H}), 7.37$ (t, $1 \mathrm{H}), 7.40$ (s, $1 \mathrm{H}), 7.48$ (t, $2 \mathrm{H}), 7.65,7.66(2 \mathrm{~d}, 4 \mathrm{H}), 8.24(\mathrm{~s}, 1 \mathrm{H}, \mathrm{NH})$; the singlet of $\mathrm{H}-8$ of the deoxyguanosine part of $5(\delta=7.40)$ is shifted markedly upfield compared to that of 3 ( $\left[\mathrm{D}_{6}\right] \mathrm{DMSO}, 300 \mathrm{MHz}, \delta=7.94$ ) and other purine nucleosides and nucleotides (see C. J. Pouchert, J. R. Campbell: The Aldrich Library of NMR Spectra. Vol. 8, Aldrich Chemical Company, Milwaukee 1974). This suggests a folded conformation for 5 in which the biphenyl moiety lies above the guanine part of the molecule and thus provides for the shielding of H-8. A similar folded conformation was found for methotextrate in an unpolar solvent ( $P$. Faupel, V. Buss, Angew. Chem. 100 (1988) 422; Angew. Chem. Int. Ed. Engl. $27(1988) 423) .{ }^{13} \mathrm{C}$ NMR: $\delta=61.8\left(\mathrm{t},{ }^{1} J(\mathrm{C}-\mathrm{H})=140.0 \mathrm{~Hz}\right), 70.7\left(\mathrm{~d},{ }^{\mathrm{I}} J(\mathrm{C}-\right.$ $\mathrm{H})=149.9 \mathrm{~Hz}), 82.0\left(\mathrm{~d},{ }^{1} J(\mathrm{C} \cdot \mathrm{H})=163.5 \mathrm{~Hz}\right), 87.2\left(\mathrm{~d},{ }^{\mathrm{t}} J(\mathrm{C}-\mathrm{H})=147.2 \mathrm{~Hz}\right)$, $125.0(\mathrm{~s}), 126.5(\mathrm{~d}, \mathrm{~J} J(\mathrm{C}-\mathrm{H})=159.5 \mathrm{~Hz}), 126.6(\mathrm{~d}, J(\mathrm{C}-\mathrm{H})=159.7 \mathrm{~Hz}), 127.0$ (s), $127.4(\mathrm{~d}, ' J(\mathrm{C}-\mathrm{H})=212.6 \mathrm{~Hz}), 127.4\left(\mathrm{~d},{ }^{\prime} J(\mathrm{C}-\mathrm{H})=162.6 \mathrm{~Hz}\right), 128.3(\mathrm{~d}$, ' $J(\mathrm{C}-\mathrm{H})=162.4 \mathrm{~Hz}), 128.9\left(\mathrm{~d},{ }^{1} J(\mathrm{C}-\mathrm{H})=161.7 \mathrm{~Hz}\right), 138.3(\mathrm{~s}), I 39.0(\mathrm{~s}), 139.6$ (s), $148.8(\mathrm{~s}), 155.4(\mathrm{~s})$; the C-2 signal of the dRibose moiety is covered by DMSO signals. MS (FD): $m / z 434\left(100 \%, M^{\oplus}\right), 318\left(78 \%, M^{\oplus}-\mathrm{dRi}\right.$ bose $+\mathrm{H}) ; \operatorname{IR}(\mathrm{KBr}): \tilde{v}=3334,2924,1658,1522,1487,1333,1086,1049,764$, $698 \mathrm{~cm}^{-1}$. UV: $\lambda_{\operatorname{mix}}=251,216 \mathrm{~nm}$.

Received: October 14, 1988 ; revised: November 28, 1988 [Z 3010 IE] German version: Angew. Chem. 101 (1989) 349

CAS Registry numbers:

$1,6810-26-0 ; 2,119273-47-1 ; 3,961-07-9 ; 4,84283-08-9 ; 5,117205-56-8$; $\mathrm{CH}, \mathrm{COCN}, 631-57-2 ; N$-(4-biphenylyl)- $O$-pivaloylhydroxylamine, $119273-$ 48-2.

[1] T. S. Scott: Carcinogenic and Chronic Toxic Hazards of Aromatic Amines, Elsevier, Amsterdam 1962.

[2] J. W. Gorrod, L. A. Damani : Biological Oxidation of Nitrogen in Organic Molecules, VCH Verlagsgesellschaft, Weinheim 1985.

[3] a) H. Bartsch, M. Dworkin, J. A. Miller, E. C. Miller, Biochim. Biophys. Acta 286 (1972) 272; see also b) E. Kriek, ibid. 335 (1974) 177; c) C. M. King, Cancer Res. 34 (1974) 1403; d) E. C. Miller, ibid. 38 (1978) 1479;

e) F. A. Beland, W. T. Allaban, F. E, Evans, ibid. 40 (1980) 834; f) E. C. Miller, J. A. Miller, Cancer (Amsterdam) 47 (1981) 2327; g) I. B. Glowinski, L. Savage, M.-S. Lee, C. M. King, Carcinogenesis 4(1983) 67; h) S. S. Thorgeirsson in H. Greim, R. Jung, M. Kramer, H. Marquardt, F. Oesch (Eds.): Biochemical Basis of Chemical Carcinogenesis, Raven Press, New York 1984, p. 47 ; i) T. J. Flammang, F. F. Kadlubar, Carcinogenesis 7 (1986) 919; j) C.-C. Lai, E. C. Miller, J. A. Miller, A. Liem, ibid. 9 (1988) 1295.

[4] L. Rehn, Arch. Klin. Chir. 50 (1895) 588.

[5] $\mathrm{N}$-Acetoxy compounds of other mutagenic and carcinogenic aromatic amines which were prepared in solution but not isolated and characterized: a) Y. Hashimoto, K. Shudo, T. Okamoto, J. Am. Chem. Soc. 104 (1982) 7636; Biochem. Biophys. Res. Commun. 96 (1980) 355; 92 (1980) 971; b) K. B. Delclos, W. G. Tarpley, E. C. Miller, J. A. Miller, Cancer Res. 44 (1984) 2540; c) A. M. Lobo, M. M. Marques, S. Prabhakar, H. S. Rzepa, J. Chem. Soc. Chem. Commun. 1985. 1113; J. Org. Chem. 52 (1987) 2925. Prepared in solution, characterized, but not isolated: 4(acetoxyamino)quinoline 1-oxide: d) Y. Kawazoe, O. Ogawa, G.-F. Huang, Tetrahedron 36 (1980) 2933; e) M. Demeunynck, N. Thome, M.F. Lhomme, J. M. Mellon, J. Lhomme, J. Am. Chem. Soc. 108 (1986) 3539 , and references cited therein. Obtained in substance and characterized $\mathrm{O}$-acetyl- $\mathrm{N}$-arylhydroxylamines: f) W. Borsche, Ber. Dtsch. Chem. Ges. 56 (1923) 1494; g) A. C. Huggett, J. L. Cone, S. S. Thorgeirsson, P. P. Roller, J. Org. Chem. 52 (1987) 4933; h) G. Boche, F. Bosold, S. Schröder, Angew. Chem. 100 (1988) 965; Angew. Chem. Int. Ed. Engl. 27 (1988) 973 ; i) $O$-acetyl- $N$-(2-naphthyl)hydroxylamine: $M$. Famulok, F. Bosold, G. Boche, Tetrahedron Lett., in press. We have also allowed 2 to react with $N$-methylaniline in analogy to the results described in Refs. [5h, i]: M. Famulok, F. Bosold, G. Boche, unpublished.

[6] Analogously to 2, we have prepared and characterized $N$-(4-biphenylyl)$O$-pivaloylhydroxylamine and allowed it to react with $3 ; 4$ and 5 were obtained in similar yields as in the case of $2 ;$ M. Famulok, F. Bosold, G. Boche, unpublished.

[7] a) F. F. Kadlubar, F. A. Beland, D. T. Beranek, K. L. Dooley, R. H. Heflich, F. E. Evans in T. Sugimura, S. Kondo, H. Takebe (Eds.): Environmental Mutagens and Carcinogens, A. R. Liss, New York 1982, p. 385 ; b) F. A. Beland, D. T. Beranek, K. L. Dooley, R. H. Heflich, F. F. Kadlubar, EHP Environ. Health Perspect. 49 (1983) 125; the authors assume hydroxylamine 1 as reactive metabolite which is formed from the $N$-glucuronide of 1 in the acid medium of the urine and reacts further after protonation at the oxygen; c) a review of "DNA adducts of aromatic amines" is given in H.-G. Neumann, J. Cancer Res. Clin. Oncol. III (1986) 100 .

[8] a) R. Shapiro, G. R. Underwood, H. Zawadzka, S. Broyde, B. E. Hingerty, Biochemistry 25 (1986) 2198. These authors also allowed $O$-acetyl$N$-(4-biphenylyl)- $N$-trifluoroacetylhydroxylamine to react with the dinucleotide $d\left(C_{p} G\right)$ under the same conditions at $37^{\circ} \mathrm{C}$ and obtained the adduct $\mathrm{d}\left(\mathrm{CpG}^{8-\mathrm{ABP}}\right)$; b) with the tetranucleotide $5^{\prime}-\mathrm{d}(\mathrm{TpGpCpA})-3^{\prime}$, the adduct $5^{\prime}-\mathrm{d}\left(\mathrm{TpG}^{8-\mathrm{ABP}} \mathrm{pCpA}\right)-3^{\prime}$ was found: D. D. Lasko, A. K. Basu, F. F. Kadlubar, F. E. Evans, J. O. Lay, Jr., J. M. Essigmann, ibid. 26 (1987) 3072.

[9] 4 and 5 were also obtained when the hydroxylamine 1 was allowed to react with DNA at pH 5 and the DNA finally cleaved enzymatically [7]: upon feeding rats with $N$-acetyl- $N$-(4-biphenylyl)hydroxylamine, 4 was detected with the help of a ${ }^{32}$ P-post-labeling assay: R. C. Gupta, N. R. Dighe, Carcinogenesis 5 (1984) 343.

[10] Acyl cyanides were used successfully for the first time for the $O$-acylation of $N$-arylhydroxylamines by S. Prabhakar, A. M. Lobo, M. M. Marques, Tetrahedron Lett. 23 (1982) 1391.

[11] LiChrosorb RP 18, $7 \mu \mathrm{m}$, preparative HPLC column $(20 \times 230 \mathrm{~mm})$, isocratic elution with methanol/water $(1 / 1)$.

\section{Photochemical Formation of a Stable Oxalic Acid Orthoamide with a Propellane Structure}

\section{By Erich Tauer,* Karl-Heinz Grellmann, Mathias Noltemeyer, and George M. Sheldrick}

We have recently reported ${ }^{111}$ that the condensation of glyoxal with 2-aminophenol does not give 2,2',3,3'-tetrahy-

[*] Dr. E. Tauer, Dr. K. H. Grellmann

Max-Planck-Institut für Biophysikalische Chemie,

Abt. Spektroskopie

Am Fassberg, D-3400 Göttingen (FRG)

Dr. M. Noltemeyer, Prof. G. M. Sheldrick

Institut für Anorganische Chemie der Universität

Tammannstrasse 4, D-3400 Göttingen (FRG) 


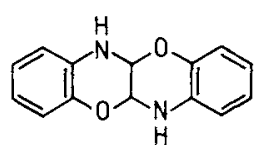

1

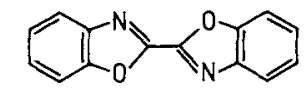

2

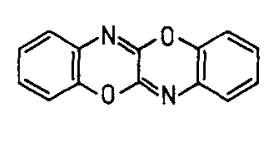

3 dro-2,2'-bibenzoxazole as was previously assumed, but affords, instead, 5a,6,11a,12-tetrahydro[1,4]benzoxazino[3,2b] 1,4$]$ benzoxazine 1 . Exposure of an air-saturated solution of 1 in an inert solvent (e.g., cyclohexane) to long wavelength light $(\lambda \geq 260 \mathrm{~nm})$ leads to the formation of $2,2^{\prime}$ bibenzoxazole 2 ; when the photolysis is performed with short wavelength light $(\lambda<260 \mathrm{~nm}),[1,4]$ benzoxazino $3,2-$ b] $[1,4]$ benzoxazine $\mathbf{3}$ is formed additionally.

In order to study the mechanism of this photooxidation reaction in more detail, we prepared derivatives and analogues of 1 , for example, the compound 5,5a,6,11,11a,12hexahydro-5,6,11,12-tetramethyl-quinoxalino[2,3-b]quinoxaline 4 which has not yet been described in the literature.<smiles>[R]N1c2ccccc2N([R])C2C1N([R])c1ccccc1N2[R]</smiles>

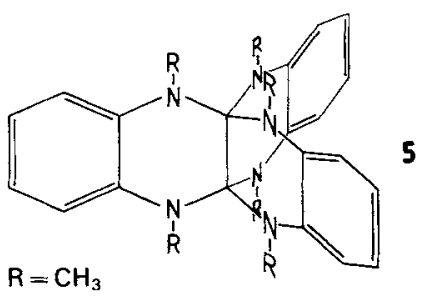

Compound 4 exhibits very surprising photochemical properties. Irradiation of a nitrogen-purged solution of 4 in cyclohexane with light of wavelength $\lambda=254 \mathrm{~nm}$ yields the oxalic acid orthoamide 5 in $11 \%$ chemical yield along with other, as yet uncharacterized photoproducts. 5 is a stable compound and can be recrystallized from ethanol. It absorbs similarly to $\mathbf{4}$ in the UV and has an unstructured fluorescence spectrum. An X-ray structure analysis ${ }^{[2]}$ (Fig. 1) showed that 5 has a $[4,4,4]$-propellane structure with the

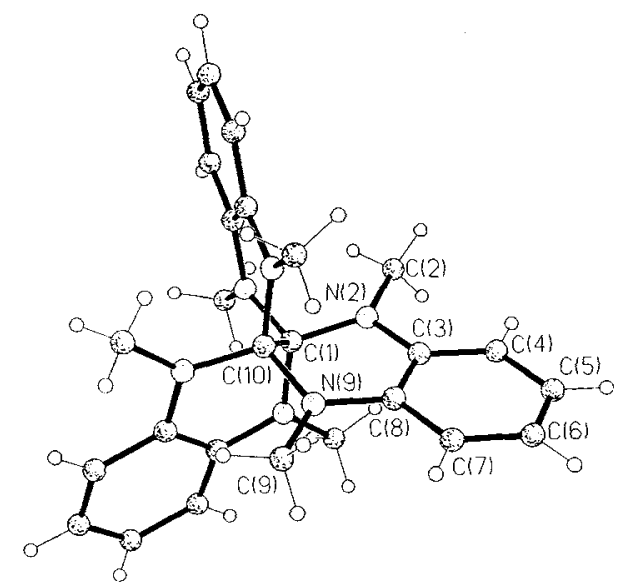

Fig. 1. Molecular structure of 5 . Selected bond lengths [pm] and angles [ ${ }^{\circ}$ : C1-C10 157.9(7), C1-N2 144.5(3), C10-N9 145.1(3), C2-N2 145.0(5), C3-C4 138.9(5), C4-C5 138.5(7), C5-C6 134.8(8), C6-C7 137.8(6), C3-C8 141.7(5); N2-C1-C10 107.2(2), C1-N2-C2 121.6(3), N2-C3-C8 120.0(3), C1-C10-N9 $107.4(2)$. molecule lying with $\mathrm{C} 1$ and $\mathrm{C} 10$ on a crystallographically exact threefold symmetry axis (symmetry position $\mathrm{x}, \mathrm{x}, \mathrm{x}$ ); the molecular symmetry is $D_{3}$. The difference electron density map showed additional maxima which were assigned to a disordered solvent molecule (ethanol), whose presence was also indicated by the elemental analysis.

Nothing is known about the mechanism of the photoreaction $4 \rightarrow 5$. To the best of our knowledge, 5 is the first orthoamide derivative of oxalic acid with the substitution pattern of a hexaminoethane.

\section{Experimental Procedure}

4: $N, N^{\prime}$-dimethyl-N, $N^{\prime}$-ditosyl-o-phenylenediamine [3] $(88 \mathrm{~g}, 0.2 \mathrm{~mol})$ was heated in a mixture of $\mathrm{H}_{2} \mathrm{SO}_{4}(80 \mathrm{~mL})$ and $\mathrm{H}_{2} \mathrm{O}(8 \mathrm{~mL})$ for $5 \mathrm{~h}$, after which the solution was poured into $300 \mathrm{~mL}$ of ice water [4]. The resulting solution was allowed to flow under $\mathrm{N}_{2}$ into $1 \mathrm{~L}$ of $\mathrm{NaOH}(6 \mathrm{M})$ and the free amine was steam distilled under $\mathrm{N}_{2}$ into a light-protected receiving flask. After ca. $3 \mathrm{~L}$ of liquid had been collected, $19.2 \mathrm{~g}$ of a $30 \%$ aqueous solution of glyoxal $(0.1 \mathrm{~mol})$ was added to the amine-water emulsion with rapid stirring. After stirring for a further $48 \mathrm{~h}$, the crude product was collected by filtration, washed with $\mathrm{H}_{2} \mathrm{O}$, and dried. Yield: $19 \mathrm{~g}(65 \%)$, m.p. $160-164^{\circ} \mathrm{C}$. Recrystallizing three times from 2-propanol $(1 \mathrm{~g} / 50 \mathrm{~mL})$ under $\mathrm{N}_{2}$ afforded colorless crystals of $4\left(14.3 \mathrm{~g}\right.$, m.p. $\left.167-169^{\circ} \mathrm{C}\right)$. ' $\mathrm{H}$ NMR $\left(80 \mathrm{MHz}, \mathrm{CDCl}_{3}\right): \delta=2.98$ $\left(\mathrm{s}, 12 \mathrm{H}, \mathrm{CH}_{3}\right), 4.28(\mathrm{~s}, 2 \mathrm{H}, \mathrm{CH}), 6.5\left(\mathrm{~m}, 8 \mathrm{H}\right.$, arylH); $\mathrm{UV}\left(\mathrm{C}_{6} \mathrm{H}_{12}\right): \lambda_{\max } / \mathrm{mm}$ $(\log \varepsilon)=312(4.11), 257(4.14), 227$ (4.81). Correct elemental analysis.

5: A solution of $4(1 \mathrm{~g})$ in p.a. cyclohexane $(1.3 \mathrm{~L})$ was photolyzed $(48 \mathrm{~h})$ in a Rayonet reactor under $N_{2}$ using 16 lamps $(\lambda=254 \mathrm{~nm})$. After removal of the solvent on a rotary evaporator, the mixture was separated chromatographically $\left(\mathrm{Al}_{2} \mathrm{O}_{3}\right.$, cyciohexane/diisopropyl ether $\left.3 / 1\right)$. It yielded $520 \mathrm{mg}$ of unreacted 4 and, after recrystallization from ethanol, $53 \mathrm{mg}(11 \%)$ of 5 as colorless crystals, m.p. $272-273^{\circ} \mathrm{C}$. MS: $m / z=426\left(M^{\oplus}\right)$; ${ }^{1} \mathrm{H}$ NMR $(80 \mathrm{MHz}$, $\left.\mathrm{CDCl}_{3}\right): \delta=2.7\left(\mathrm{~s}, 18 \mathrm{H}, \mathrm{CH}_{3}\right), 6.5-6.85\left(\mathrm{~m}, 12 \mathrm{H}\right.$, arylH); UV $\left(\mathrm{C}_{6} \mathrm{H}_{12}\right): \lambda_{\text {mix }} /$ nm $(\log \varepsilon)=316(4.38), 310(4.34), 250(4.33, \mathrm{sh}), 227$ (4.99); fluorescence: $\lambda_{\max }=347 \mathrm{~nm}$ (line width $50 \mathrm{~nm}$ ). Correct elemental analysis.

Received: October 17, 1988 [Z 3012 IE] German version: Angew. Chem. 101 (1989) 350

CAS Registry numbers:

4, 13784-23-1; 5, 118894-97-6; $N, N^{\prime}$-dimethyl- $N . N^{\prime}$-ditosyl- - -phenylenediamine, 29627-62-1; glyoxal, 107-22-2.

[1] E. Tauer, K. H. Grellmann, E. Kaufmann, M. Noltemeyer, Chem. Ber. 119 (1986) 3316.

[2] 5.0.5 EtOH: cubic, space group $P a \overline{3}, a=1677.6(5) \mathrm{pm}, V=4.7213 \mathrm{~nm}^{3}$, $Z=8, \rho_{\text {caicd }}=1.299 \mathrm{~g} \mathrm{~cm}^{-3}, \mu=0.08 \mathrm{~mm}^{-1}\left(\mathrm{Mo}_{\mathrm{K} \alpha}\right) ; 6934$ intensities measured to $2 \theta=45^{\circ}, 968$ symmetry independent reflections with $F>3 \sigma(F)$ used in the structure solution (SHELXS-86) and refinement (SHELX-76), non-hydrogen atoms anisotropic and $H$ atoms as rider model, $R=0.090$, $w R=0.092, w^{-1}=\sigma^{2}+0.0008 F^{2}$. Further details of the crystal structure investigation may be obtained from the Fachinformationszentrum Energie, Physik, Mathematik GmbH, D-7514 Eggenstein-Leopoldshafen 2 (FRG), on quoting the depository number CSD-53369, the names of the authors, and the journal citation.

[3] Synthesis according to H. Stetter, Chem. Ber. 86 (1953) 161.

[4] Hydrolysis according to G. W. H. Cheeseman, J. Chem. Soc. 1955, 3308.

\section{$(t \mathrm{BuSiP})_{4}$-The First Silaphosphacubane ${ }^{* *}$}

By Marianne Baudler, * Guido Scholz, Karl-Friedrich Tebbe, and Magda Fehér

Although a large number of phosphorus-silicon heterocycles having various molecular frameworks are already known, ${ }^{1,21}$ a silaphosphane with a cubane structure has yet to be reported. We have now prepared the first silaphosphacubane, closo-tetrakis(tert-butylsilylphosphane) 1 , and

[*] Prof. Dr. M. Baudler, G. Scholz, Prof. Dr. K.-F. Tebbe, Dr. M. Fehèr Institut für Anorganische Chemie der Universität Greinstrasse 6, D-5000 Köln 41 (FRG)

$\left[{ }^{* *}\right]$ Contributions to the Chemistry of Phosphorus, Part 192. This work was supported by the Minister für Wissenschaft und Forschung des Landes Nordrhein-Westfalen and the Fonds der Chemischen Industrie. Part 191: M. Baudler, C. Block, H. Budzikiewicz, H. Münster, Z. Anorg. Allg. Chem., in press. 